of a middle or lower Cretaceous connection with Greenland, an hypothesis fully in harmony with the views of a connecting off shore Tertiary terrane, advanced by certain Neocene palæontologists.

There remain still many problems in the stratigraphy and chronology of Gay Head. Next year will doubtless offer opportunities for fresh conclusions, at least on subordinate points, to my frienor any other geologist. There may even be good reasons for the sincere entertainment of almost fundamentally different opinions on the part of an equally skilful observer.

Among other problems, not merely local, is the circumstance that, notwithstanding the incompatibility and irrationality of the idea in view of present continental geography and topography, no other inherent evidence has, I beliere, been found as to the deposition of the clays and sands of this series except such as tends to support the view of Professor Uhler that these middle or lower Cretaceous terranes are essentially fresh water formations.

Washington, D.C., Nov. 16.

DAVID WHITE.

\section{On the Vernacular Name of the Genus Harporhynchus.}

THAT well-known genus of American birds, of which Harporhynchus rufus is the type, is almost universally called in English, by every ornithologist, or indeed by every one who knows the species in the United States, a Thrasher. In New England, and to the southward and westward, it is known as the Brown Thrasher. We find it printed Thrasher in the A. O. U. CheckList, without any synonymic term or terms, as is also the case in such an authorative work as Coues's "Key to North American Birds." Now it is of interest to know that our British ornithological friends call these birds Threshers, spelled with an $e$ in the first syllable, instead of an $a$. Recently Professor Alfred Newton submitted me the proof of a contribution of mine to bis extensive work on Ornithology, now passing through the press, wherein this word occurred,- spelled Thrasher in my text, but Thresher in a supplementary note of his own. Upon his attention being called to it, I received from him the following in his repls: "I have not the least wish to interfere with your use of Thrashers, there is some authority for it among English writers, - but I believe Thresher to be more correct (A. S., perscan or pirscan; Mid Engl., preschen; Chaucer, threshen; Scal., preskja; Old Dutch, derschen; Germ., dreschen; Gothic, thrisken) and prefer that form for my own use - though, of course, giving it the sound of short ă, as in many other words, e.g., Derby. Thrash would seem to indicate a pronunciation like Thrāsh (almost tbrarsh) which is local and vulgar. A. N." This communication is dated Magdalene College, Cambridge, England, Nov. 12, $1892 . \quad$ According to this it would seem that our old, time-honored name of Thrasher. strictly speaking, sbould give way to the more correct appellation of Thresher.

Takoma, D. C., Nov. 29.

\section{Meteoric Shower.}

THE meteoric shower here on the evening of Nov. 23 was very fine. The average of several observations, from $;$ to 10 P.M, gare 250 good-sized meteors per minute, with a great many very small ones resembling a fiery dust. The meteors appeared to radiate from a point nearly orerhead at 9 P.M.

Austerlitz Mine, Oro Blanco, Pima County, Ariz., Nov. 26.

\section{Remains of the Mastodon Recently Found in Tennessee.}

Near Niebert's Springs, seven miles south-east of Knoxville, some workmen recently unearthed four molar teeth of the mastodon, which were in a fair state of preservation. They were found beneath about thirty inches of yellow tenaceous clay, containing water-worn stones. The largest tooth measured sixteen inches in circumference, and bears on its grinding surface one small and four large ridges, which are covered to the depth of one fourth of an inch with perfectly preserved enamel. The smallest tooth measures twelre inches in circumference, and has only three transverse ridges, whose surfaces are so worn as to expose the dentine in a number of places. The roots are so decayed and broken that it is impossible to determine their original length or number.

The University of Tennessee has in its possession other remains recently found in Hawkins County of this State. These consist of part of a tusk, measuring twenty-two inches in circumference by twelve inches in length, and a molar tooth with only two ridges. The tooth is well preserred; but the tusk is much decayed.

S. W. McCallie.

University of Tennessee, Knoxville, Tenn.

\section{The Humming-Bird's Food.}

THE notes that have recently appeared in Science regarding the humming-bird's food, would seem to show that the bird's taste varies with the locality. In southern New York their favorite flower is the swamp-thistle (Cirsium muticum). No better place could be selected for studying the feeding-habits of the rubythroats than a spot where these flowers abound. Dr. Gibbs thinks the individual flowers of the red clover too small for the ruby-throat's attention, but in the thistles the flowers are even smaller. Since it has been said that the bee gets pollen but not honey from the thistle, it would appear that the birds visit these flowers for insects. There is scarcely a flower that contains so many minute insects as a thistle-head. Examine one with a lens and it will be found to contain many insects that can hardly be seen with the unaided eye. If the ruby-throat eats insects at all, these are the ones it would take; and because the larger ones remained the observer might conclude that none were eaten.

Bir ghampton, Now York, Nov. 21. Winlard N. Clute.

\section{AMONG THE PUBLISHERS.}

"General TAYLOR," a biography by Major-General O. O Howard, U.S. A , will follow Mahan's "Farragut" in the Great Commander Series published by D. Appleton \& Co. General Howard has visited the scenes of Taylor's campaigns in Mexico, and his book will be found to be an authority for those who are interested in the military history of our country. This biography contains a portrait and several maps.

- Mecmillan \& Co. announce the publication of a new work on the heavens and their origin, under the title of "The Visible Universe," by J. Ellard Gore, F.R.A.S., the author of "Star Groups," etc. The book is a discussion of the theories which have been advanced from time to time as to the construction of the heavens, celestial chemistry, stellar distances and motions, etc., and is illus' rated by stellar photographs and lithographic plates.

- The January St. Nicholas will contain the opening paper in a series that magazine is to print on leading American cities, illustrated. In this article Colonel T. W. Higginson describes Boston in a way to interest boys and girls in the literary history of that city. For future numbers of St. Nicholas, Dr. Lyman Abbott will write of Brooklyn, Edmund Clarence Stedman will describe New York, and other famous residents of the different cíties will describe them.

- "Electric Light Cables and the Distribution of Electricity, "by Stuart A. Russell, is the latest volume in the Specialists' Series (London, Whittaker \& Co.; New York, Macmillan). The recent extension of electric lighting from large central stations has brought to the front many problems connected with the economical distribution of electricity over large areas; and to the discussion and elucidation of these problems this volume is devoted. In its 319 pages the author presents a clear, reasonably comprehensive, and fully illustrated description of the various systems of distribution and types of conductor now in use, and suggests the directions in which future improvements will be made. Price, \$2.25.

- The Appalachian Mountain Club has just published a second work, with the title, "The Land of the Cliff-Dwellers," from the pen of Mr. Frederick H. Chapin. The region to which the reader 


\section{Science}

\section{On the Vernacular Name of the Genus Harporhynchus}

R. W. Shufeldt

Science ns-20 (514), 333

DOI: 10.1126/science.ns-20.514.333

ARTICLE TOOLS

http://science.sciencemag.org/content/ns-20/514/333.1.citation

PERMISSIONS

http://www.sciencemag.org/help/reprints-and-permissions 